\title{
Colourful Antioxidants for Environmental Toxicity Assessment
}

\section{Wong Ling Shing*}

Faculty of Science, Technology, Engineering, and Mathematics, INTI International University, 71800 Nilai, Negeri Sembilan, Malaysia

Pigments such as chlorophylls and carotenoids produce colours for the plants- chlorophylls make the leaves green, while carotenoids are responsible for the yellowish to red colours. These pigments are important, for their distinct function in light harvesting for photosynthesis, as well to protect the plants from reactive oxygen species [1].

In healthcare, these plant-origin pigments serve as antioxidant supplement to human.Antioxidants help in eliminating free radicals that responsible for the oxidation and degradation of biomolecules [2]. By reducing the free radicals, the risk of many types of diseases can be reduced. In fact, chlorophylls have been recommended by medical expert for its therapeutic value as early as 1940 [3]. The pigments were later beingreported to be able to inhibit carcinogens in vitro [4] and contribute to better healing of severaldiseases. On the other hand, carotenoids which appear to be widely available pigments have turned out to be an important supplement with therapeutic values for human $[5,6]$.

The antioxidant property of the pigments from the plants has been utilized in different ways in environmental toxicity assessment. These pigments have been used as the reporter groups for biosensors, as they produce certain biological signals after been exposed to the environmental pollutants, such as heavy metals and pesticides.

The most recent research showed that carotenoids contained in Daucuscarota (carrot) can be used to detect the presence of heavy metal [7]. The detection was made possible by coupling the cell to spectrophotometer. The change in the content of carotenoids (predominantly $\beta$-carotene) after been exposed to heavy metal was detected by the absorbance at $450 \mathrm{~nm}$. Chlorophylls have been extensively studied for the fluorescence characteristic for environmental toxicity assessment [8-10], as the change of fluorescence intensity before and after the exposure to environment toxicants is a good indication to determine the presence of the toxicants.
As chlorophylls and carotenoids keep our body in good health by scavenging the oxidants, the pigments help to monitor our environment for pollutants too. As many expects are yet to be studied on what the pigments can do to human's health, and there are many more exploration that we can do on using these pigments in environmental toxicity assessment as well. Of course, when we talk about the pigments in environmental applications, the question which might rise is- What about other pigments other than chlorophylls and $\beta$-carotene?

\section{References}

1. Garrett RH, Grisham CM (2010) Biochemistry, 4th ed. United States of America: Brooks/Cole CengageLearning

2. Simao AA, Santos MAI, Fraguas M, Braga MA, Marques TR, et al. (2013) Antioxidants and chlorophyll in cassava leaves at three plant ages. African Journal of Agricultural Research 8: 3724-3730.

3. Gruskin B (1940) Chlorophyll- Its therapeutic place in acute and suppurative diseases: Preliminary report of clinical use and rationale. The American Journal of Surgery 49: 49-55.

4. Chiu NL (1979) Chlorophyll: The active factor in wheat sprout extract inhibiting the metabolic activation of carcinogens in vitro. Nutrition and Cancer 1: 19-21.

5. Melendez GV, Okani ET, Kiertsman B, Roncada MJ (1995) Vitamin A status in children with pneumonia. Eur J Clin Nutr 49: 379-384.

6. Mayne ST (1996) Beta-carotene, carotenoids, and disease prevention in humans. FASEB 10: 690-701.

7. Wong LS, Choong CW (2012) The responses of natural cell-bounded carotenoids to short term of exposure of heavy metals. IPCBEE 44: 65-69.

8. Wong LS, Lee YH, Salmijah S (2012) The Fluorometric Response of Cyanobateria To Short Exposure of Heavy Metal. Advances in Environmental Biology 6: 103-108.

9. Wong LS, Lee YH, Salmijah S (2013) Whole cell biosensor using Anabaena torulosa with optical transduction for environmental toxicity evaluation. Journal of Sensors 8.

10. Védrine C, Leclerc JC, Durrieu C, Tran-Minh C (2003) Optical whole-cell biosensor using Chlorella vulgaris designed for monitoring herbicides. Biosens Bioelectron 18: 457-463.

*Corresponding author: Wong Ling Shing, Faculty of Science, Technology, Engineering and Mathematics, INTI International University, 71800 Nilai, Negeri Sembilan, Malaysia, Tel: +6067982000; Fax: +6067997536; E-mail: lingshing79@yahoo.com.sg

Received August 23, 2013; Accepted August 24, 2013; Published August 28 2013

Citation: Wong LS (2013) Colourful Antioxidants for Environmental Toxicity Assessment. J Biomol Res Ther 2: e114. doi:10.4172/2167-7956.1000e114

Copyright: (c) 2013 Wong LS. This is an open-access article distributed under the terms of the Creative Commons Attribution License, which permits unrestricted use, distribution, and reproduction in any medium, provided the original author and source are credited. 